\title{
Exploring the possibility for African traditional religion to be included in a reimagined scriptural reasoning model
}

\begin{tabular}{|c|c|}
\hline \multicolumn{2}{|c|}{$\begin{array}{l}\text { Author: } \\
\text { Maniraj Sukdaven }{ }^{1}\end{array}$} \\
\hline \multicolumn{2}{|c|}{$\begin{array}{l}\text { Affiliation: } \\
{ }^{1} \text { Department of Science of } \\
\text { Religion and Missiology, } \\
\text { Faculty of Theology and } \\
\text { Religion, University of } \\
\text { Pretoria, South Africa }\end{array}$} \\
\hline \multicolumn{2}{|c|}{$\begin{array}{l}\text { Research Project Details: } \\
\text { Project Leader: M. Sukdaven } \\
\text { Project Number: } 04616546\end{array}$} \\
\hline \multicolumn{2}{|c|}{$\begin{array}{l}\text { Description: } \\
\text { This research is part of } t \\
\text { research project, 'Africa } \\
\text { Written Intellectual Her } \\
\text { directed by Dr Maniraj } \\
\text { Sukdaven, Department } \\
\text { Science of Religion and } \\
\text { Missiology, Faculty of } \\
\text { Theology and Religion, } \\
\text { University of Pretoria. }\end{array}$} \\
\hline \multicolumn{2}{|c|}{$\begin{array}{l}\text { Corresponding author: } \\
\text { Maniraj Sukdaven, } \\
\text { sukdavenm@gmail.com }\end{array}$} \\
\hline \multicolumn{2}{|c|}{$\begin{array}{l}\text { Dates: } \\
\text { Received: } 15 \text { Aug. } 2018 \\
\text { Accepted: } 01 \text { Sept. } 2018 \\
\text { Published: } 22 \text { Nov. } 2018\end{array}$} \\
\hline \multicolumn{2}{|c|}{$\begin{array}{l}\text { How to cite this article: } \\
\text { Sukdaven, M., 2018, } \\
\text { 'Exploring the possibility for } \\
\text { African traditional religion to } \\
\text { be included in a reimagined } \\
\text { scriptural reasoning model', } \\
\text { HTS Teologiese Studies/ } \\
\text { Theological Studies 74(3), } \\
\text { a5224. https://doi.org/ } \\
\text { 10.4102/hts.v74i3.5224 }\end{array}$} \\
\hline $\begin{array}{l}\text { Copyright: } \\
\text { (c) 2018. The } A \\
\text { Licensee: AOS } \\
\text { is licensed un } \\
\text { Creative Comr } \\
\text { Attribution Lic }\end{array}$ & $\begin{array}{l}\text { luthors. } \\
\text { IS. This work } \\
\text { ler the } \\
\text { nons } \\
\text { ense. }\end{array}$ \\
\hline Read online: & \\
\hline 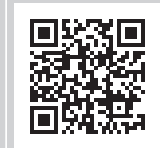 & $\begin{array}{l}\text { Scan this QR } \\
\text { code with your } \\
\text { smart phone or } \\
\text { mobile device } \\
\text { to read online. }\end{array}$ \\
\hline
\end{tabular}

In and among the many models developed for engaging in inter-religious dialogue was a model that became known as scriptural reasoning (SR). SR basically serves the purpose of being hospitable towards the Abrahamic religions. The current approach of SR, by virtue of its focus only on scripture as the basis of engagement, obviously excludes other faith traditions that possess no sacred scripture. One such religion is African traditional religion (ATR). As a result of this exclusion, this article intends to engage SR to consider reinterpreting imaginatively, or to use a synonym, to reconceptualise, its basis of only scripture as the primary source of engagement and as such to expand its basis to include religions with an oral-orientated tradition. This article explores such a possibility for the inclusion of ATR, as an oral tradition, to be considered as an equal partner in a reimagined SR or as a parallel model with similar guidelines and outcomes as found in SR.

\section{Introduction}

Hans Küng (1991), who is an advocate for inter-religious dialogue, firmly believes that there can be no peace without religions entering into dialogue with one another. In this regard he also pleads for:

a more intensive philosophical and theological dialogue of theologians and specialists in religion which takes religious plurality seriously in theological terms, accepts the challenge of the other religions, and investigates their significance for each person's own religion. (pp. 137-138)

This is indeed a profound statement from Küng. His call was for an inclusive participation of all religions in inter-religious dialogue. Cognisance must be taken of the fact that such dialogues can take place at different levels with different models appropriate for the dialogue. I see scriptural reasoning (SR) as one such model that emerged for embracing inter-religious dialogue with certain restrictions. I believe it is a commendable model that can serve as a basis to develop into an inclusive parallel model of all religions in a global society.

SR was always an engagement between Judaism, Christianity and Islam. It is not about finding commonality; neither is it to be seen as a foundational approach, where exclusivity forms the basis of the approach to SR. Nor is it about finding agreements, though there may be, but rather it is about learning to disagree better (Moyaert 2013:73). It is about engaging the difficult texts, asking the difficult questions and allowing the text to speak, even to the detriment of populous beliefs about a text. It is indeed reasoning around scriptural texts of these three religions.

In the discussions that follow, and in its current state, SR can be construed as an exclusive club where three particular religions engage in inter-religious dialogue. The context from which SR grew is understood and accepted, but, for the purpose of including other non-scriptural religions, this method of approach needs to be reconsidered, reimagined and possibly a parallel model developed.

Most, if not all, non-scriptural religions tend to rely on an oral transmission of their beliefs and practices from one generation to the next. Most of these religions are known as primal religions or preliterate religions and as such never had the ability to codify their oral transmission such as Judaism, Christianity and Islam, which were also, at some point, oral traditions.

In the discussion that ensues in this article, and because I am an African, I will focus on African traditional religion (ATR), which is an oral tradition, and why it should be considered for inclusion 
in this reimagined SR inter-religious dialogue. In an attempt to accomplish this I will:

1. briefly address the purpose of SR

2. explain the challenges of primary sources for ATR

3. explore a new form of approach that will be inclusive of ATR.

\section{What is scriptural reasoning?}

Throughout human history, religion influenced and regulated the lives of people. Religion, in this sense, must be seen in the broader definition rather than just the idea of faith in a transcendent being. Therefore, religion may be expressed as a set of beliefs and practices described as abstract (faith) and concrete (material). Inasmuch as ethical norms and values are encapsulated in religion and practices, religion has been at the forefront of religious violence and extremism. SR, as a model for inter-religious dialogue, has been developed to address this problem and find a way for peaceful (co)existence among adherents of different religions.

A very simple explanation of SR would be the reciprocal hosting of others of the Abrahamic faith around scripture. The key word, around which the 'reasoning' here is centred, is 'scripture'. The intention is not to seek agreement or disagreement about other religions' scriptures but to learn to accommodate or show hospitality toward the views of other religions regarding scripture, even though one may disagree. Hardy (2006) supports this notion by stating that:

SR concerns itself with the primary discourse of God in the particularities ... as seen through ... particular interpretation of ... particular Scriptures, not in order to compare them and derive what is thought to be common to them, but in order to allow them to disagree or agree and by doing so illuminate the others. (p. 530)

The main aim of this process is to learn to disagree better, thus the term 'reasoning' rather than 'debating', because debating has the connotation, although not necessarily in this strict sense, of trying to prove one right and the other wrong, with the intention of winning the argument with persuasion.

\section{The birth of scriptural reasoning}

SR was not born in a vacuum even though religious violence and extremism existed during its birth. This model idea was born out of a previous exercise within Judaism. The coming together of Jewish thinkers to address classical Jewish texts and rabbinical traditions of interpretation, in order to respond to postmodern challenges, developed dialogical and exegetical methods that culminated in what came to be known as 'textual reasoning' (TR). This concept of TR gave rise to SR.

Kevin Hughes (accessed 12 July 2018), in addressing 'what is scriptural reasoning', states that SR had borrowed its essence from TR by taking 'what has been learned in the interplay between Jewish forms of reading and postmodernity and extend those learnings in the arena of Jewish-ChristianMuslim dialogue'. Even though the participating religions in SR were, and still are to a large degree, based on the Abrahamic religions (Judaism, Christianity and Islam), the reason for this is the context from which it was born. The following statement of purpose extracted from the SR website (www.scripturalreasoning.org) provides an excellent basis for the birth of SR and how it developed into a model for SR. It states that:

Textual reasoning was a university-based forum for scholars of Modern Jewish Philosophy and scholars of Rabbinic texts to meet and study together. The aim was to grow in understanding of the different disciplines, and to approach key questions about Judaism in the present and future. In the mid 1990's, some Christian friends of members of the Textual Reasoning group sat in on the conversation, and were so attracted by the lively process that they suggested using it as a model for inter-faith conversations. Later, Muslim friends were invited to join the conversation, and 'Scriptural Reasoning' was born. The first Christian participants were from the UK, and the practice quickly spread across the Atlantic. Before long, it also began flourishing among non-academic groups. (http:/ / www.scripturalreasoning.org/the-history-of-scripturalreasoning.html)

This origin of SR, which focused only on the Abrahamic religions, was encapsulated by a statement by Hardy (2006), who suggested that:

[f]or a member of one Abrahamic tradition to participate with members of others in the study of his/her and their Scriptures, respectfully and interactively, is the fons et origo - the "source and origin" - of Scriptural Reasoning. (p. 530)

Even Ford (2006:273) suggested that SR could be 'understood as a wisdom-seeking engagement with Jewish, Christian and Muslim scriptures'. Cheetham (2014) opines in the video "'Scriptural Reasoning and the Meeting of Abrahamic Faiths: An Aesthetic Politics of Religions", supports the notion that scriptural reasoning is the coming together of people of the Abrahamic faiths'. In this video he describes SR as 'Christians, Muslims and Jews [who] come together specifically around the discussion of their scriptures ...'.

In briefly considering what SR is, how it was born and the involvement of only the Abrahamic religions, the question that now needs to be asked is whether all non-scripturalbased religions can be considered and how can these religions be involved in such endeavours so as to reimagine this model or develop a parallel model of SR to be inclusive of all religions while maintaining the basic characteristics of the current guidelines of SR?

\section{The inclusion of other religions in scriptural reasoning}

The concept of SR was to create a model for inter-religious dialogue, which, as described, was born out of the Jewish 
model of TR. Inasmuch as the Abrahamic religions are currently the only participants in SR, Gibbs (2006:526) suggests that even though there are good reasons for the Abrahamic religions to be read together, he nevertheless concedes that there 'is not an a priori exclusion of other religious traditions, say Confucian or Hindu or Buddhist'. One can assume that his rationale may be that these religions also have scripture that fulfils the basis for their participation in SR. This opinion of non-exclusion of other religious traditions by Gibbs gained traction and support when Peter Ochs (2013) responded to Yang Huilin, who wanted SR to be extended to the Chinese scriptures. Ochs responded to Huilin via his paper, 'A Relational (nonbinary) Semeiotic for Scriptural Reasoning', which he read at the XXth Congress of the International Comparative Literature Association, that the Chinese scriptures can be included in SR if guided by models derived from the initial practices of both TR and formational SR. It can already be observed, therefore, that SR is open for the inclusion of other religions on condition that it meets certain prerequisites.

But what about religions that do not have scriptural texts or creeds? Should such religions be excluded from SR dialogues or should another model be developed that can arise from SR, while maintaining its core philosophical base of 'reading' together with the 'primary discourse of God in the particularities' (Hardy 2006:530). It has been 23 years since the birth of SR as an inter-religious model of dialogue and no concrete evidence exists of expanding this concept of SR or developing another model based on the guidelines of SR to be inclusive of all religious traditions.

It stands to reason, from the preceding arguments, that ATR will automatically be disqualified because of its non-scriptural existence. With this said, I want to nevertheless suggest that SR either expand its criteria for only scripture as its basis or develop a second, but parallel model, in which I want to suggest that SR be reimagined to include the oral tradition of ATR. For this second parallel model, many of the present guidelines (Ford 2007:279-280; Kepnes 2006:378-383; Moyaert 2013:72-73) for SR can also be reimagined to accommodate the oral tradition of ATR. In this article I will not recommend any guidelines but I will present a position that needs to be considered, recommending inclusion of the oral tradition of ATR.

\section{Incorrect approaches to dialogue with African traditional religion}

Ilo (2016:185) lists three reasons why reconciliation with other faiths in Africa and especially ATR failed to bear fruits. The first reason pertains to what I translate as 'superior mentality'. This is evident when Ilo (2016:186) suggests that the conversations with African traditional religionists were 'very top-down, very confessional in nature, and lacking serious attempts to dialogue from the margins or from the point of view of vulnerability or to listen to their voices'.

The second reason is the disregard for context of the ATR. It seems that a universal template for dialogue was adopted in engaging ATR. Ilo (2016:186) admits that this approach has failed and that unique African cultural approaches to reconciliation 'have not been mined in much ecumenical and interfaith dialogue'.

The third reason seems to be that these dialogues stagnated at statements and declarations. In this regard, Ilo (2016:186) suggests that the failure was because of a 'lack of prophetic steps and actions that will move the conversations beyond joint statements and declarations'.

To his credit, Ilo $(2016: 186,187)$ does offer five 'shifts', which he believes are necessary for 'reimaging' African Christianity in its quest for reconciliation in Africa. It is not my intention to discuss these five shifts but rather to focus in the context of this article on how to use the shortcomings expressed by Ilo to develop a model for inter-religious dialogue.

I want to address the first two reasons by focusing on (1) what Ilo (2016:186) refers to as listening to their voices, and to which I will add the oral tradition, and (2) the African culture, to which I will add arts, symbols and materiality. To this second part many other African traditions and elements can be added, but I wish to restrict myself to only these three: arts, symbols and materiality. I also would like to add (3) a third contribution. This contribution will focus on written sources of scholars, researchers, archaeologists and sociologists and how this impacts on ATR as a means of understanding the ATR.

\section{Sources for understanding African traditional religion}

A foremost scholar in ATR, John Samuel Mbiti (1931-) has produced many scholarly books and articles on ATR. In one such book, African Religions and Philosophy (1969), Mbiti succeeded in producing a seminal work on African traditional philosophy. An excerpt from the second edition of the book, for those interested in studying ATR, explains that one of the difficulties posed by:

... studying African Religions and philosophy is that there are no
sacred scriptures. Religion in African societies is written not on
paper but in people's hearts, minds, oral history, rituals and
religious personages like the priests, rainmakers, officiating
elders and even kings. Everybody is a religious carrier. Therefore
we have to study not only the beliefs concerning God and the
spirits, but also the religious journey of the individual from
before birth to after physical death; and to study also the persons
responsible for formal rituals and ceremonies. What people do is
motivated by what they believe, and what they believe springs 
from what they do and experience. So then, belief and action in African traditional society cannot be separated: they belong to a single whole. (Mbiti 1990:3-4)

Notwithstanding that ATR does not have any written text as scripture, a sense of what ATR is can be gauged from the combination of both the emic and etic research approach. There are nevertheless two sources from which one can have a fairly accurate understanding of ATR. These are referred to as primary and secondary sources. A brief overview of these sources will assist in authenticating the ATR as a serious partner in a reimagined or parallel model for SR.

Amanze (2007), in his article published in Ministry Magazine, explains the primary source as (1) oral. This includes 'myths, traditional events told as stories, as well as proverbs and wise sayings that contain the philosophy and worldviews of the people. Liturgy, worship recitals, and songs are also integral parts of this source'. (2) Concrete. This includes ecological landmarks such as sacred trees, rivers, mountains, forests, rocks and artistic objects. The secondary sources will refer to published works such as books and articles by researchers, renowned authors and practitioners of the religion.

\section{The primary sources for African traditional religion}

It is interesting to note the lament from Magesa when referring to the dialogue between Christianity and ATR. He believes that there was never a 'real conversation' but that:

[c]ontact between Christianity and African Religion has historically been predominantly a monologue, bedevilled by assumptions prejudicial against the latter, with Christianity culturally more vocal and ideologically more aggressive. Therefore, what we have heard until now is largely Christianity speaking about African Religion, not African Religion speaking for itself. (Magesa 1998:16)

When ATR begins to speak for itself, it offloads the onceopinionated Western world assumption of Africa being a barbaric, uncivilised continent that needs religion and civility. In the lament by Magesa, there is a definite call to '[l]isten to their voices', as suggested by Ilo (2016:186), and by listening one is able to comprehend and admit that traditional Africa believed in a supreme being even before the West had an inkling of god. This is further substantiated by the 'concrete' primary source, as explained by Amanze (2007). The term 'concrete' in this instance should be understood as opposed to 'abstract'. It should be understood as fact, that which can be substantiated. These concrete primary sources find substantiation in archaeological and anthropological studies of ATR. With this said, I am not in any way suggesting that 'concrete' evidence is required to prove the veracity of the oral tradition. Therefore, in this section I will interpret both ' $[l]$ isten to their voices' as directly related to the oral tradition, and the 'concrete' as that which is tangible, to constitute the primary source.

The religions that SR is engaged in, Judaism, Christianity and Islam, were all rooted in an oral tradition. In order to interpret these texts, different methodologies of interpretations, including historical, hermeneutical and linguistic approaches, were adopted to correctly elucidate many of these texts in these scriptures in order for it to be as meaningful today as it was for the people who transmitted it and those who wrote it.

Currently, almost all oral transmittals are being researched and many have been in one way or another documented. The research and documentation certainly had its challenges, which Vasina (1961) addressed comprehensively. Some of the issues raised in the research and documentation of oral traditions centred on the validity of the transmittals as a historical source. Two major questions highlighted by Vasina (1961:1) that needed to be addressed were whether the memories of succeeding generations of the transmittals can be relied upon. The two major questions therefore were: (1) do they a priori deprive oral tradition of all validity as a historical source and, if not, then (2) are there means of testing its reliability? To both these questions, Vasina (1961:1) concluded that indeed oral traditions 'are not necessarily untrustworthy ... [and] merits a certain amount of credence within certain limits'. $\mathrm{He}$ also did not rule out auxiliary sources such as archaeology, cultural history, linguistics and physical anthropology as historical source materials to supplement the oral traditions.

While Vasina (1961) addressed the nature of oral traditions as a historical source and stated that as such they can be construed as a primary source, Draper and Mtata (2012) added another dimension by correctly suggesting that:

African religion is not only oral in its orientation; it is essentially 'performative' and 'communal' and as such 'even' when religious tradition has been recorded or transcribed and printed by Western anthropologists, transcriptions of African religious oral texts cannot speak by themselves. The oral texts must be performed in order to be effective. (p. 97)

This is also the position of Tasie (2013:32-33). He holds firm to the understanding that, with reference to myths, songs, proverbs, adages, idioms, wise sayings and legends, indeed ATR, as an oral tradition, serves as a vehicle to understanding African beliefs and practices. $\mathrm{He}$ nevertheless also opined for these primary sources to be documented for posterity.

Although the historical sources of information, in determining whether oral traditions can be valid, have been questioned by mainly Western writers, Vasina (1961), Draper and Mtata (2012) and Tasie (2013) have all agreed that oral traditions can be trustworthy, are 
essentially performative and communal and do reflect on the beliefs and practices, and in this case this is also true for ATR.

We have established that oral religious traditions, and for the purpose of this article, ATR, can certainly be accepted as a religion that is not inferior and, despite not having scripture, also not less true than Judaism, Christianity or Islam in the eyes of the African traditional practitioner. Judaism, Christianity and Islam also evolved from an oral tradition but were then codified. The major challenge is to determine on what basis can ATR be critically and objectively pursued in dialogue with other religions, because, as discussed earlier, it is difficult to dispute the traditions and beliefs of those practising African religion?

There is certainly a need to have the ATR codified, but this is an extremely difficult task because of the diversities that exist in Africa. According to Mbiti (1990:1) there are approximately 3000 tribes, each with its own religious system. In Hinduism we also have serious diversities of philosophies, yet it was able to codify its philosophies in the compilation of the Vedas and subsequent literature. How then can a parallel model of SR be reimagined or developed to welcome ATR to the dialogue table with other religions?

With the complexities expressed thus far, and as Vasina (1961) concluded that ATR 'merits a certain amount of credence within certain limits' regarding its inclusion in a reimagined or parallel model of SR, I want to therefore, in conclusion, explore the possibility of considering material religion as a basis for a reimagined or parallel model of SR. This concept of material religion can be more accommodating in a parallel model of SR, which will not carry the suspicious baggage that an oral tradition brings with it as alluded to earlier. Stephenson $(2010: 507,508)$, in his review of the book Materializing Religion: Expression, Performance and Ritual, edited by Elisabeth Arweck and William Keenan, stated that ' $t]$ he move to studying material and performative culture as a corrective to an over emphasis on texts and textualism is now several decades old'. The point in this statement here is twofold: (1) it can be construed that the study of material religion was pursued because of an overemphasis on texts and (2) that the studying of material religion is only 'several decades old'. This statement is significant because it does offer a valuable reason for material religion to be considered as a possible and probably better alternative to oral tradition for a reimagined or parallel model of SR. Can a reimagined or parallel model of SR accommodate the idea of material religion within its sphere of inter-religious engagement, which may not have to digress significantly from the guidelines of SR as it currently stands? I believe it is worth exploring as I turn to a brief understanding of material religion.

\section{Material religion}

After rejecting the Protestant construct of religion and therefore also a Western construct, Chidester (2018), in an interesting explanation of maintaining the term religion in material religion, suggests that the term be retained in the study of material religion in order to 'signal a terrain in which human beings engage in meaningful and powerful ways with the material constraints and animations of matter ...'. With this turn to the study of material religion, Chidester (2018:3) elaborates further that studying material religion focuses on the material conditions of possibility for negotiating the human rather than on religion as a construct of the West. What can be gathered from Chidester's critique of religion reaffirms the concrete nature of material religion in juxtaposition with the abstract nature of religion purported by Western constructs.

In addressing the one-sided Protestant focus on beliefs, Strijdom (2014:1) uses the example of Calvinists here to express the sentiments of Chidester by stating that 'a myriad of objects, bodily performances, sensations, emotions and gestures play a much more important role in Calvinism than usually acknowledged'.

Therefore, religion redefined needs to be considered as a material practice without sacrificing the abstract nature of religion but including its concrete nature. In this regard Hutchings and McKenzie (eds) (2017:6) suggest that 'belief itself can be studied from a materialist perspective' and that ' $[b]$ eliefs are learned, experienced and adapted through embodied engagement in rituals, relationships and practices'. Here we find a distinctive correlation between belief and materiality. This correlation was identified in the first issue of the journal Material Religion.

In the first issue of the journal Material Religion, the editors (Meyer et al. 2005:6) correctly observed that the study of religion was seen as the study of texts - liturgical, theological, poetic or narrative words and concepts. This is justified because for the last 3000 years printed texts have been seen as authoritative (Meyer et al. 2005:6).

However, according to these editors (Meyer et al. 2005), 'the limits of a textual study of religion have gradually been recognised by many in academe, museum, and elsewhere over the last two or three generations', thus causing them to believe that:

the study of texts should be joined to the study of objects, spaces, images, and all the practices that put these items to use in order to arrive at a more robust account of how religion works in the lives of its adherents and in the societies that shape and are shaped by a religion. Often, however, texts are lacking. Prehistoric religions have generally left only objects, images, markings, and spaces for us to puzzle over what religious practices and beliefs occupied such long lost peoples. Ancient religions frequently offer only scraps of textual remains. In other instances closer to the present, texts were destroyed or lost 
to the ravages of time, leaving us once again with the deductive work that the study of material forms offers historical understanding. (p. 6)

This elaborate quote offers many reasons why a reimagined or parallel model of SR could accommodate other religions that do not have scripture as a source document for their beliefs and practices, to sit at the table of interreligious dialogue. Anderson (2013:102) also contends for art as a 'well suited resource for dialogue among religions, most of which have rich traditions of material culture'. The preceding quote highlights many issues raised in this article that should be considered for a reimagined SR.

\section{Conclusion}

This article attempted to explore the possibility for the ATR to be included in a reimagined SR. The article presented a brief overview of SR and its origin, then addressed the issue of oral tradition as the tradition of ATR and the value attached to the oral tradition together with its challenges. Considering these challenges to an oral tradition, the article then turned to material religion as a source for consideration in a reimagined or a parallel model of SR. The article did not develop a theory of how this should be done but only explored the possibilities of such a consideration. More thought needs to be given as to how material religion can be added to the table, what guidelines need to be considered and how such a suggestion can be successful. The inclusiveness of any model of inter-religious dialogue should always be explored. ${ }^{1}$

\section{Acknowledgements Competing interests}

The author declares that he has no financial or personal relationships which may have inappropriately influenced him in writing this article.

1.The Department of Religion Studies at the University of Pretoria will be giving this exploration serious attention in developing a possible reimagined or parallel model of SR while maintaining the basic guidelines of SR in an inclusive form of inter-religious dialogue in conjunction with members of the SR movement.

\section{References}

Amanze, P.O., 2007, God of the Africans: Ministering to adherents of African traditiona religion, viewed 29 July 2018, from www.ministrymagazine.org/archive/2007/10/ god-of-the-africans.html

Anderson, M., 2013, 'Art and inter-Religious dialogue', in C. Cornille (eds.), The WileyBlackwell companion to inter-religious dialogue, pp. 99-116, Wiley-Blackwell, Chichester.

Cheetham, D., 2014, Scriptural reasoning and the meeting of Abrahamic Faiths: An Aesthetic Politics of Religions, video recording, YouTube, viewed 05 May 2018, https://youtu.be/kDITaVthsIU

Chidester, D., 2018, Religion: Material dynamics, University of California Press, Berkeley, CA.

Draper, A.J. \& Mtata, K., 2012, 'Orality, literature and African Religions', in E.K. Bongmba (eds.), The Wiley-Blackwell Companion to African Religions, 1st edn., Blackwell Publishing, Chichester.

Ford, D.F., 2007, Christian wisdom: Desiring God and learning in love, Cambridge University Press, New York.

Gibbs, R., 2006, 'Reading with others: Levina's ethics and Scriptural Reasoning', Modern Theology 22(3), 515-528. https://doi.org/10.1111/j.1468-0025.2006.00332.x

Hardy, D.W., 2006, 'The promise of scriptural reasoning', Modem Theology 22(3), 530-551. https://doi.org/10.1111/j.1468-0025.2006.00333.x

Hughes, K., What is scriptural reasoning, viewed 12 July 2018, from http://www61. homepage.villanova.edu/kevin.hughes/what_is_scriptural_reasoning.html

Hutchings, T. \& McKenzie, J., 2017, 'Introduction: The body of St Cuthbert', in T. Hutchings \& J. McKenzie (eds.), Materiality and the study of religion: The stuff of the Sacred, pp. 1-13, Routledge, Abingdon.

Ilo, S.C., 2016, 'Cross currents in African Christianity. Lessons for intercultural hermeneutics of friendship and participation', in V. Latinovic, G. Mannion \&
P.C. Phan (eds.), Pathways for interreligious dialogue in the twenty-first century, pp. 183-196, Palgrave Macmillan, Hampshire.

Kepnes, S., 2006, 'A handbook for scriptural reasoning', Modern Theology 22(3), 367-383. https://doi.org/10.1111/j.1468-0025.2006.00323.x

Küng, H., 1991, Global responsibility: In search of a new world ethic, Crossroad publications, New York.

Magesa, L., 1998, African Religion. The moral traditions of abundant life, Paulines Publications, Nairobi.

Mbiti, J.S., 1990, African religions and philosophy, Heinemann, Oxford.

Meyer, B., Morgan, D., Paine, C. \& Plate, S.B., 2005, 'Editorial statement', Material Religion 1(1), 4-9.

Moyaert, M., 2013, 'Scriptural reasoning as inter-religious dialogue', in C. Cornille (eds.), The Wiley-Blackwell companion to inter-religious dialogue, pp. 64-86, Wiley-Blackwell, Chichester.

Ochs, P., 2013, A Relational (non-binary) Semeiotic for Scriptural Reasoning, viewed 30 July 2018, from www.academia.edu/8141580/A_Relational_non-binary Semeiotic_for_Scriptural_Reasoning

Statement of Purpose, The history of scriptural reasoning, viewed 12 July 2018, from www.scripturalreasoning.org/the-history-of-scriptural-reasoning.html

Stephenson, B., 2010, 'Materializing Religion: Expression, Performance and Ritual', Church history. Studies in Christianity and culture 79, 507-508. https//doi. org/10.1017/ S0009640710000491

Strijdom, J.M., 2014, 'The material turn in Religious Studies and the possibility of critique: Assessing Chidester's analysis of 'the fetish', HTS Teologiese Studies/Theological Studies 70(1), Art \#2116, 7 pages. https//doi.org/10.4102/hts.v70i1.2116

Tasie, G.I.K., 2013, 'The heritage of the mouth: Oral sources and the study of African Tradition Religion', International Journal of Humanities and Social Science Invention 2(3), 26-34.

Vasina, J., 1961, Oral tradition: A study in historical methodology, transl H.M. Wright (1965), Routledge, London. 